\title{
PRODUCTION CONTROL BY TAXATION
}

\author{
David F. Cavers*
}

The pressure for compulsory control of cotton production may be traced to two sources: fear that the voluntary reduction of cotton acreage would not work a corresponding reduction in cotton production, and fear that the voluntary program would collapse if non-coöperators were able to reap benefits in higher prices attributable to their neighbors' participation without the burden of restrictive agreements. The objective of the draftsmen of the production control legislation with respect to cotton was, therefore, the dual one of reducing production to a level deemed economically sound under current conditions and at the same time of giving sanction to the voluntary program by penalizing the non-coöperating producer.

In the case of tobacco, since the voluntary program itself provides for production control, ${ }^{1}$ only the latter of the two fears inspiring the cotton legislation was operative. But the risk that the voluntary program would break down if non-coopperators were permitted to share in higher prices was a real one. Coöperative associations have been wrecked on this same rock. ${ }^{2}$

The two acts which embody these efforts, the Bankhead Cotton Control Act ${ }^{3}$ and the Kerr Tobacco Control Act, ${ }^{4}$ merit careful examination wholly apart from the question of their economic soundness or their consonance with "fundamental American principles," except insofar as these may be invoked before the Supreme Court. Assume their economic justification, grant their political desirability; the pragmatic question still remains: will they work? This article is not intended to furnish a Delphic response to that question. It seeks merely to depict the machinery through which these acts must work, if at all.

- B.S. in Econ., 1923, University of Pennsylvania; LL.B., 1926, Harvard. Member of New York Bar. Professor of Law, Duke University. Editor, LAw and Contemporary Problems. Contributor to legal periodicals.

${ }^{2}$ See Knapp and Paramore, Flue-Cured Tobacco Developments under the AAA, supra at p. 341. Production control agreements exist for other tobacco types, cigar leaf excepted.

'See Hanna, Agricultural Coöperation in Tobacco, supra at pp. 309-10, 313.

'Act of April 21, I934, Public, No. 169, 73rd Cong., 2nd Sess. (hereinafter cited as the "Bankhead Act"). The Act derives its name from its chief sponsor, Senator John H. Bankhead of Alabama.

"Act of June 28, 1934, Public, No. 483, 73rd Cong., 2nd Sess. (hereinafter cited as the "Kerr Act"). The Act derives its name from its chief sponsor, Representative John H. Kerr of North Carolina. 
I

\section{The Bankhead Cotton Control Act}

The plan of the Bankhead Act may be indicated in bold outline as follows: A tax is to be levied on the ginning of cotton harvested in the crop year $1934-35^{\circ}$ (and, if the emergency persists and producers favor its continuance, in the crop year $1935-36$ ) at the rate of $5^{\circ}$ per cent of the average market price for spot cotton. Ten million bales of this cotton are exempted for the crop year 1934-35. The Secretary of Agriculture is to apportion this exempt cotton among the cotton-producing states on the basis of their production over a period of five years prior to the passage of the Act. This allotment is in turn to be apportioned among the counties of each state on a similar basis and, finally, among the farmers of each county who agree to abide by the agricultural adjustment program. The basis for apportionment to individual producers may be either the past production of their farms or the past potential productivity-or any other basis deemed "fair and just" by the Secretary. Provision is made for the allocation of a portion of each state's quota to certain classes of producers who would suffer hardship were any of the general bases applied to them. Transferable exemption certificates are to be issued to allottees provided they have agreed to comply with the acreage reduction program. Upon the surrender of the certificates (or the payment of the tax) bale tags are affixed to the cotton covered thereby. Transportation of untagged cotton beyond county lines is forbidden. Provision is made at every turn for the promulgation of regulations by the Secretary to implement the statute. A few of these have been promulgated; others have been issued in "preliminary," unofficial form..$^{5 *}$ So important are the regulations to an understanding of the Act's operation that reference will be made on occasion to the latter. Revision in detail only is anticipated:

\section{Declaration of Policy}

Faithful to the current mode, the Act begins, with an apologia in the form of a "declaration of policy" which is set forth in full below:

That in order to relieve the present acute economic emergency in that part of the agricultural industry devoted to cotton production and marketing by diminishing the disparity between prices paid to cotton producers and persons engaged in cotton marketing and prices of other commodities and by restoring purchasing power to such producers and persons so that the restoration of the normal exchange in interstate and foreign commerce of all commodities may be fostered, and to raise revenue to enable the payment of additional benefits to cotton producers under the Agricultural Adjustment Act-

"The "crop year" for cotton is defined as running from June $I$ of one year to May 31 of the succeeding year. Bankhead Act, $\$ 23$ (i).

ta Regulations have been issued to provide for the tagging of ginned cotton harvested before 1934.35. Application forms for exemption certificates have also been issued. To guide field workers in their use, instructions have been distributed which include draft regulations governing the apportionment of allotments, issuance (but not transfer) of exemption certificates, and related matters. Instructions and Regulations Pertaining to the Cotton Act of April 21, 1934 (Preliminary) Dept. AGr., AAA, June 25, 1934. [An] examination of a revision of these "Instructions," issued July 7, 1934, and information received as to the official regulations promulgated too late for incorporation herein, indicate that $\mathrm{few}$, if any, changes have been made in the latter relevant to matters discussed herein.-D. F. C.] 
It is hereby declared to be the policy of Congress to promote the orderly marketing of cotton in interstate and foreign commerce; to enable producers of such commodity to stabilize their markets against undue and excessive fluctuations, and to preserve advantageous markets for such commodity, and to prevent unfair competition and practices in putting cotton into the channels of interstate and foreign commerce, and to more effectively balance production and consumption of cotton.

\section{The Tax}

The tax imposed by the Bankhead Act is on the transaction of ginning cotton, not on the cotton ginned. ${ }^{6}$ Presumably, therefore, it will be regarded as an excise tax and not as a direct tax, subject to the requirement of apportionment. ${ }^{7}$ The amount of the tax is " 50 per centum of the average central market price per pound of lint cotton but in no event less than 5 cents per pound." This price is to be determined "from time to time" by the Secretary of Agriculture by reference to the average price of $7 / 8$ inch middling spot cotton on the ten spot cotton markets. ${ }^{9}$ The ginner is to pay the tax and make returns monthly to the Commissioner of Internal Revenue. ${ }^{10}$ Obviously the tax will be immediately passed on to the person for whom the cotton is ginned.

Once the determination was made to curb cotton production above a given level, one may well inquire why there should have been resort to a tax upon ginning to enforce this decision rather than to an express limitation upon production. A partial answer lies in the fact that neither Congress nor the producer can determine what will be the yield of a given acre planted to cotton. It is obvious that in certain areas, production quotas will be exceeded. Supervision cannot well be exercised in the field, but the cotton ginneries through which all cotton must pass afford a point at which control can be effectively applied. Why, then, was a limitation not placed upon the amount that might be ginned? This, in fact, was what the bill first introduced by Senator Bankhead purported to do. ${ }^{11}$ The change to a taxing measure, which took place in committee, may have been dictated by the following considerations. If the prohibition had been absolute, the temptation to "bootleg" seed cotton produced in excess of allotments would have been great. The taxing measure is more elastic. The tax may be paid on non-exempt cotton and the grower will receive a substantial return. There is a risk, however, that unless the tax plus the costs attributable to intensive cultivation exceeds the anticipated price of cotton, it will not operate to discourage deliberate efforts to produce in excess of allotments. ${ }^{12}$

'Ibid., $\$ 4$ (a).

"No capitation, or other direct, tax shall be laid, unless in proportion to the census of enumeration.

" U. S. Const., Art. I, $\$ 9$, cl. 4 .

Bankhead Act, $\$ 4$ (a). The rate first proposed was 75 per cent.

Ibid., $\varsigma_{4}$ (b).

${ }^{10}$ Ibid., $\$ 4$ (c).

${ }^{11}$ See S. 1974, 73rd Cong., 2nd Sess. (r934).

22 The items of cost attributable to the more intensive cultivation of cotton are chiefly the cost of the additional fertilizer applied and the extra cost of picking. In some instances, where high yields can be obtained it seems clear that excess production will be profitable even though the margin per bale will be small. 
A second consideration which may have been influential lies in the fact that resort to an excise tax gives color to the contention that the Act is based on the taxing power of Congress, not on the commerce power, which would avoid, if successful, the thorny question of whether the commerce power extends to a regulation of cotton production. $^{13}$

\section{Exemptions}

The tax is imposed only on cotton harvested in a crop year to which the tax is applicable. ${ }^{14}$ Consequently cotton harvested prior to $1934-35$ is exempt. Persons owning such exempt cotton may secure bale tags which "shall be promptly affixed to the bales of lint cotton so held." 15 Cotton grown by publicly owned experimental stations and agricultural laboratories is also exempt. ${ }^{16}$ So, too, is cotton having a staple one and' one-half inches in length or longer. ${ }^{17}$.

The chief significance of the tax exemption lies, however, in the fact that it is the device through which compulsory production control is linked to the voluntary acreage reduction program. Certificates of exemption are to issue to the cotton producer, whether or not a signer of the 1934-35 acreage reduction contract, who agrees to "comply with such conditions and limitations on the production of agricultural commodities by him as the Secretary of Agriculture may, from time to time, prescribe. ..."18 (It is to be noted that this obligation is not confined to cotton production.) The basis for determining the allotments of cotton to be covered by these exemption certificates will be considered in the succeeding section.

Cotton harvested in a taxed crop year is subject to tax whether ginned that year or thereafter, ${ }^{19}$ but "the producer" who desires to store his cotton "either on the farm or at such other place as may be permitted by regulations" need not pay the tax at the time of ginning. ${ }^{20}$ Bale tags may be secured for stored cotton at any time after ginning upon the payment of the tax or the surrender of the exemption certificates covering it, but until that time the cotton thus stored is to be subject to a tax lien in favor of the United States. ${ }^{21}$ Regulations will doubtless minimize the risk of illicit disposition.

\section{Apportionment}

The total amount of cotton to be apportioned for allotment under exemption certificates is fixed at 10,000,000 500-pound bales for the crop year 1934-35.22 Should the Act be applied the year following, the Secretary of Agriculture is to determine the amount to be allotted "from an investigation of the available supply of cotton

\footnotetext{
${ }^{12}$ The regulatory character of the Act is but slightly veiled, however. Note the somewhat inconspicuous reference to the raising of revenue contained in the recitals in the declaration of policy. See p. 350, supra. See Maggs, Congressional Power to Control Cotton and Tobucco Production, infra, p. 376.

"s Bankhead Act, $\$_{4}$ (a).

${ }^{15} I$ Ibid., $\$ \$ 4$ (c) (3), Io (c). $\quad{ }^{17} I$ Ibid., $\$ 4$ (c) (4).

${ }^{28}$ Ibid., \$6. "No criminal penalties shall apply to the violation of this provision." Id.

19 Ibid., $\$ 4$ (a).

so I2icis., \$4 (i).

2 Id.

${ }^{\text {s }}$ lbid., $\$_{3}$ (c).
} 
and the probable market requirements" and proclaim the amount so ascertained at least 60 days before the beginning of that crop year. ${ }^{23}$

The allotment problem was one of the knottiest encountered by the framers of the Act. The determination of a base period for apportionment among the cotton states was charged with political dynamite. Because of the shifting trends in cotton production in recent years, the length of the base period affected materially the allotment to the various cotton-producing states. A five-year period preceding the passage of the $\mathrm{Act}^{24}$ was finally chosen in lieu of the ten-year period originally proposed.25 With an eye to the Commerce Clause. Congress declared the allotment to be for the purpose of preventing "unfair competition and unfair trade practices in marketing cotton in the channels of interstate and foreign commerce"26 and followed this declaration with a further genuflection to the Supreme Court in the form of a "prima facie" presumption that "all cotton and its processed products move in interstate or foreign commerce."27

A similar base period was chosen for allotments by the Secretary of each state's quota among its constituent counties. ${ }^{28}$ It was provided, however, that there should be omitted from a county's base period any year in which natural causes (floods, droughts, pests, etc.) reduced production therein to an abnormally low level. ${ }^{29}$ In the apportionment of a state's quota, moreover, an amount not exceeding Io per cent was to be withdrawn for special distribution, ${ }^{30}$ to be discussed below.

Less fraught with political complications than apportionment among the states but more difficult from the standpoint of providing workable machinery was the task of providing standards for apportioning county quotas among individual producers. Two standards were furnished the Secretary, followed by an invitation to him to devise a better one. ${ }^{31}$ However, only one standard may be applied within any single county.

${ }^{23}$ Ibid., $\$_{3}$ (a) (b).

"Ibid., $\$ 5$ (a).

${ }^{25}$ Sce S. 1974, 73rd Cong., 2nd Sess. (1934).

${ }^{\infty}$ Bankhead Act, 85 (a).

$\approx$ Id.

${ }^{23} 1$ bid., $\$ 5$ (b). The change was to the disadvantage of North Carolina, Oklahoma, and Texas, where cotton production had been reduced voluntarily by producers during the five year period chosen. A proviso added at the instance of Senator Johnson in behalf of California provided that no state should receive an allotment of less than 200,000 bales if in any year during the base period it had produced 250,000 bales. Bankhead Act. $\$ 5$ (a). Missouri benefitted from this clause also. The substitution of a fixed minimum allotment for the base-period led to difficulties when it became necessary to make allotments among counties in states having the 200,000 bale allotment. This difficulty was ironed out by an amending measure subsequently enacted. H. J. Res. 369, 73rd Cong. 2nd Sess. (1934).

$\approx$ Bankhead Act, \$5 (b).

${ }^{*}$ Ibid., $\$ 8$.

8s "Such allotments to any farm shall be made upon application therefor and may be made by the Secretary based upon-

(x) A percentage of the average annual cotton production of the farm for a fair representative period; or

(2) By ascertaining the amount of cotton the farm would have produced during a fair representative period if all the cultivated land had been planted to cotton, and then reducing such amount by such pereentage (which shall be applied uniformly within the county to all farms to which the allotment is 
The method of apportionment is not susceptible of easy description. A base production figure is determined for each applicant as follows. ${ }^{32}$. For each year during the base period in which cotton was planted on the applicant's farm, he lists and multiplies the number of bales produced by the average net weight per bale, giving thereby the total lint produced. This in turn is divided by the acreage planted to cotton for that year, giving the yield per acre. (Where, however, cotton had been planted for three or less years during the base period, a county average yield is substituted.) These figures are totaled for all years in the base period in which cotton was planted, and averages taken. These averages may be adjusted by the County Committee, the adjusted average of total production constituting the production base.

In the case of farmers who have signed the 1934-35 acreage reduction contract, the foregoing figures, including the adjusted averages, are already available. In order to determine the allotment base for these applicants, it is necessary only to multiply the adjusted average yield per acre by the number of acres permitted by the contract to be planted to cotton. To ascertain the allotment base for non-signers once the adjusted averages are arrived at, the production base is multiplied by a percentage figure which represents the average percentage of the base.acreage that contract signers in the county are permitted to plant. Thus, if a non-signer had a production base of ro,000 pounds of lint per year, and if the average reduction of acreage in the county were $3^{8}$ per cent, then his allotment base would be 62 per cent of ro,000 pounds, or 6,200 pounds.

The proportion of any individual's allotment base to the total of all producers' allotment bases in the county indicates the percentage of the county's allotment which will be allocated to that producer. Thus, if the 6,200 pounds in the example given constitute one per cent of the total allotment bases for a county having an allotment of 1,000 bales (500,000 pounds) the applicant would receive a 5,000 pound allotment. The existence of a fixed county allotment nullifies the effect of mass exaggeration. The retrospective optimist whose figures are accepted may get an allotment greater than he deserves, but he does so at the expense of his fellow-farmers within his county.

The foregoing method of allotment does not achieve justice in those cases where the production over the base period is not such as to afford a representative basis for allotments. This difficulty was anticipated by the framers of the Act, who provided, as has been noted, that a reserve of ro per cent of each state's total allotment should be set aside for distribution in special cases. These were classified by the statute as made under this paragraph) as will be sufficient to bring the total of the farm allotments within the county's allotment; or

(3) Upon such basis as the Secretary of Agriculture deems fair and just, and will apply to all farms to which the allotment is made under this paragraph uniformly, within the county, on the basis or classification adopted. ..." Bankhead Act, $\$ 7$ (a) (1) (2) (3). The first basis is not to be used after the crop year I934-35. Ibid., \$7 (b).

82 The procedure described in the text is based on Instructions and Regulations Pertaining to the Cotton Act of April 2I, 1934 (Preliminary), stupra note 5a, Pt. V, and on the application Forms Nos. B. A. 8a and B. A. 9, U. S. Dept. Agr. (AAA), May 29, 1934. 
follows: (a) farms where for the preceding three years less than one-third of the cultivated land had been planted to cotton; (b) farms not previously used therefor; (c) farms where, for the preceding five years, normal production had been reduced by uncontrollable natural cause; and (d) farms where, for the preceding three years, cotton acreage had been reduced in excess of a reasonable reduction program. ${ }^{33}$

The Act did not, however, indicate just what was to be done in these cases. This has been determined by the Secretary. ${ }^{34}$ In class (b) where no cotton had been planted in the base period an estimate of cotton production for 1934 is made on the basis of the average yield for the county. In the other cases, the allotment given is to be in addition to that received under the regular procedure. In class (a), an estimate is made of the production if one-third of the cultivated land had been planted to cotton. The adjusted average production for the base period is then subtracted from this estimated production, and the difference represents the addition to the regular allotment base. Where, in class (c), there had been in any year a yield onethird below the five-year adjusted average, that year is excluded in the computation of a new average production. The difference between this new average and the adjusted average represents the addition to the allotment base. Where, in class (d), cotton acreage in the period 1930-32 was less than 60 per cent of cotton acreage in I929, a new average production is calculated by assuming cotton acreage to have been 60 per cent of the r 929 acreage. The difference between this new average and the adjusted average constitutes the addition to the allotment base.

Of course, only that percentage of these additional allotment bases which the state reserve bears to the total of all additional allotment bases will actually be allotted. What is to be done in the event that this percentage exceeds roo per cent has not been specified; apparently the question is academic.

\section{The Protection of the Share-Tenant and Cropper}

A problem which has already perplexed the AAA in its administration of the voluntary program promises to rise again-the protection of the share-cropper and tenant. In authorizing the Secretary to make regulations protecting their interests in the making of allotments and the issuance. of exemption certificates, ${ }^{85}$ the Act has afforded an opportunity to correct what seems heretofore to have been a want of vigilance on the part of the AAA in behalf of this submerged class. ${ }^{36}$

Except where a share-tenant or cropper operates a farm "in its entirety"-the exceptional case-application for an allotment is to be made by the landlord.37 Where he has share-tenants or croppers, he must accompany his application with a sworn statement setting forth the estimated cotton production of each tenant and

${ }^{25}$ Bankhead Act, $\$ 8$. These allotments are to be in addition to the regular county allotment. Id.

2 The classification in the text is derived from application Form No. B. A. 8a, supra note 32.

25 Bankhead Act, \$15 (b).

${ }^{20}$ See Bruton, Cotton Acreage Reduction and the Tenant Farmer, supra at p. 286.

${ }^{27}$ The discussion in this section of the text is based on Instructions and Regulations Pertaining to the Cotton Act of April 21, 1934 (Preliminary), supra note 5a, pp. 8-12, 36-41, and the application Forms Nos. B. A. 8 and B. A. 9, supra note 32 . 
cropper for 1934, together with the estimated production of land farmed by him personally or by wage labor. The figures thus obtained, when reduced to percentages of his farm's total estimated production, will serve as a basis for allocating the exemption certificates among the landlord, his share-tenants, and croppers. The latter must be given notice of the estimates of their 1934 production. The aggrieved tenant is entitled to a hearing before the county committee which has power to correct the submitted figures. Debts owing to the landlord are not to affect allotments.

Apparently to prevent the landlord from claiming surplus certificates from the cropper who has failed to "make" his allotment while at the same time benefitting from surplus cotton produced by the cropper who has exceeded his allotment, an ingenious scheme has been worked out-especially ingenious in that it penalizes the cropper who has failed to work in good faith to produce his allotment. Special provision is made for the informal transfer within any farm of certificates between tenants and croppers until the full allotment of cotton to all tenants and croppers on that farm has been covered. If, however, after such adjustment, there still remains a surplus of certificates, they are not to be transferred by the regular procedure but must be returned to the county office for cancellation. New certificates in equal amount are then issued to all tenants and croppers on that farm in proportion to the original allotments given them. Suppose a farm has three croppers, A, B, and $C ; A$ and $B$ having allotments of 4 bales each and $C$ having one of 8 bales. $A$ and $B$ each produce but 2 bales while $C$ produces 6 , leaving a farm surplus of croppers' certificates amounting to 6 bales. Certificates for this surplus will be reissued to $A, B$, and $C$ in amounts of $1 \frac{1}{2}, 1 \frac{1}{2}$, and 3 bales respectively. These certificates may be transferred in the usual manner. The result is that $C$ will have received one bale more than his original allotment while $A$ and $B$ will each have received $1 / 2$ bale less than theirs. The landlord's allotment will not have been affected by the transaction.

Where a landlord's affidavit that a share-cropper or tenant has abandoned a crop without cause before gathering is found after investigation to be true, the Secretary may cancel the latter's certificates and reissue certificates to the landlord in an amount necessary for the allotment covering the abandoned crop. Surplus certificates are to be sold and the proceeds deposited in trust for the tenant or cropper.

A share-tenant or cropper usually arranges for the ginning of the entire crop produced by him, including the landlord's share. It is required that landlords contribute certificates covering their share of such crop to make possible the marketing of the whole tax free.

These proposed regulations seem to have been inspired by a genuine desire to insure fair treatment to the share-tenant and cropper. There is no doubt but that they will, if promulgated, encumber the administration of the Act and prove a burden to landlords of large estates. Perhaps they will not achieve their goal. Such a failure would seem fairly attributable to the limitations inherent in legal machinery when charged with the task of overcoming a profound social mal-adjustment. 
Tax-Exemption Certificates and Bale-Tags

The tax-exemption certificate to be issued consists of a series of nooo numbered coupons each representing five pounds of tax-exempt cotton. The heading of the certificate bears the name of the person to whom it was issued and the application serial number of the tarm. Coupons are worthless if detached from the certificate by persons other than ginners or authorized government agents. The ginner removes the number of coupons representing the net weight of cotton ginned and thereupon affixes a bale tag identifying the cotton as tax-exempt (or, in case of actual payment, tax-paid). ${ }^{38}$

The certificates are transferable in accordance with regulations prescribed by the Secretary. Forms to facilitate transfer are to be supplied, but obtaining certificates or bale tags by "sharp practices," fraud, or coercion is made a penal offense. ${ }^{39}$ A penalty is also imposed on speculation in certificates or tags, ${ }^{40}$ an offense which will call for definition. Possibly an official discount rate will be established for certificates. The rate of discount would probably vary inversely with the estimated production in excess of the $10,000,000$ bale allotment.

The proposed regulations as to share-tenants and croppers suggest that restrictions will be placed upon the transfer of certificates issued to them prior to the harvesting of the crop. Unless this is done, it is difficult to see how the elaborate provisions for re-distribution of surplus certificates and for cancellation in case of crop-abandonment can be effectuated. Certainly every effort should be made to avoid the risk of social dislocation which would arise from placing in the hands of poverty-stricken and ignorant tenantry certificates which can lawfully be cashed in advance of harvesting the crop. The temptation to realize on this novel asset, even at an improvident discount, might prove irresistible.

It seems likely that the producer with a surplus will seek to acquire certificates rather than dispose of his seed cotton, although there is no restriction upon its sale or transportation (except for export). ${ }^{41}$ Possibly farmers will store their surplus in the hope that a future indulgent Congress will free it from the tax. However, proper storage facilities for seed cotton are limited.

Traffic in untagged lint cotton is closely restricted. It may not be transported beyond the county of production except for purposes of storage, and no untagged bales may be sold, purchased or opened. ${ }^{42}$ Criminal penalties sanction these prohibi-

\footnotetext{
* See Instructions and Regulations Pertaining to the Cotton Act of April 21, 1934 (Preliminary), supra note 5a, Pt. VII. Provision has also been made for an interim certificate for use where regular certificates have not been issued prior to the opening of the ginning season. The interim certificate covers not to exceed 50 per cent of the applicant's $1934-35$ crop. It is not transferable.

Bankhead Act, $\$ 9$ (d).

${ }^{20} \mathrm{Id}$.

al The export of seed cotton is prohibited, ibid., $\mathrm{SI}_{4}$ (c), obviously an essential requirement to prevent widespread evasion through ginning in foreign countries.

$\checkmark$ Ibid., $\$_{14}$ (b). These prohibitions may be relaxed by regulations prescribed "with due regard for the protection of the revenue."
} 
tions. ${ }^{43}$ If adequate supervision can be exercised at the ginneries-and there are over 13,000 of them-these prohibitions would seem effective since the withdrawal of untagged lint cotton for storage would be recorded. Another risk of evasion lies in the re-use of bale tags or of tagged bales. This is rendered a criminal offense, as is the forgery or counterfeiting of certificates or tags. ${ }^{44}$

\section{Administration of the Act}

The administration of the Act is vested in the Secretary of Agriculture, with the exception of certain functions entrusted to the Treasury Department. He is authorized to make appointments without regard to civil service requirements. ${ }^{45}$ The actual work of administration has been turned over to the AAA which has organized "County Production Control Associations" composed of cotton producers for local administration. ${ }^{46}$ The checking of producers' reports will be undertaken by "Community Committees" and "County Committees." The field official is the County Agent of the Extension Service who, in the larger counties, is aided by an "Assistant in Cotton Adjustment." "The same general procedure will be followed as was uised in the 1934 and 1935 cotton-acreage reduction plan." 47

Taxes are to be collected by the Commissioner of Internal Revenue and paid into the United States Treasury, ${ }^{48}$ but the proceeds are "authorized to be appropriated to be made available" for use in the AAA cotton program and for the administration of the Act itself for which, however, additional appropriation is made of sums available under the Agricultural Adjustment Act. ${ }^{48}$

A final section, following a little forlornly the section on definitions, authorizes the Secretary to expend $\$ 500,000$ "to develop new and extended uses for cotton."

\section{Continuance of the Act}

After the crop year 1934-35, the continuance of the Act is contingent upon a finding by the President that "the economic emergency in cotton production and marketing will continue or is likely to continue to exist so that the application of the Act with respect to the crop year $1935-36$ is imperative in order to carry out the policy declared in section r." If If the President proclaims the Act to be effective for that year, the Secretary of Agriculture, before making allotments of exempt cotton, must ascertain whether two-thirds of the persons "who have the legal or equitable right as owner, tenant, or share-cropper, or otherwise to produce cotton" in the United States "favor a levy of a tax on the ginning of cotton in excess of an allotment made to meet the probable market requirements." 52 If two-thirds of such producers

s'The penalty is liability to a fine of not more than $\$ 1,000$ or to not more than one year's imprisonment, or both. Ibid., $\$ \mathrm{SI}_{4}$ (d). The violation of regulations for which no special penalty is provided is penalized by a fine of not more than $\$ 200$. Ibid., $\$$ I 4 (e).

"For penalties, see note 43, supra.

${ }^{4}$ See Preliminary Questions and Answers covering the Bankhead Act, U. S. Dept. AGr. (AAA), May 2, 1934, P. II.
"Id.
"Bankhead Act, $\$$ rg.
-Ibid., 516 (a) (b) (c).
${ }^{50}$ lbid., 524.
${ }^{31}$ Ibid., \$2.
${ }^{2 x}$ Ibid., $\$ 3$ (a). 
refuse to endorse such a tax, no allotment may be made, and the tax does not become applicable. The method whereby the Secretary shall ascertain this sentiment is not specified. $\$ 8$

II

\section{The Kerr Tobacco Control Act}

The Kerr Act is a simpler measure than its prototype, the Bankhead Act, and since, moreover, regulations as to it are not available, a less detailed examination of its provisions is called for. A tax is imposed on the "first" sale of tobacco at the rate of $33 \frac{1 / 3}{3}$ per cent of the selling price unless the Secretary of Agriculture designate a lower rate (not to be less than 25 per cent).$^{54}$ This tax is payable by the seller ${ }^{55}$ and is to be applied, with certain exceptions, ${ }^{56}$ to all tobacco harvested in the crop year 1934-35. It may be extended to the succeeding year only if the Secretary determines that three-fourths of the growers favor its continuance and, further, that its imposition is necessary to effectuate the declared policy. of the Act. ${ }^{57}$ Tobacco produced before the r934-35 season is exempt from tax and is to be identified as such by tag or otherwise. ${ }^{58}$

The tobacco production adjustment program, unlike the cotton program, was not limited to acreage reduction. Agreements providing for benefit payments were made on the basis of an allotment to each producer of a given number of pounds of tobacco in addition to rental payments for reductions in acreage.58 The Kerr Act rewards the contracting producer by providing for the issuance to him of tax-payment warrants covering an amount of tobacco equal to the amount allotted him under his agreement with the Secretary. ${ }^{60}$ The existence of such allotments obviated the necessity for the elaborate machinery for state, county, and individual allotments which is found in the Bankhead Act. However, an alternative basis for allotment is provided by a clause permitting the issuance of tax-payment warrants to the extent of the estimated production on "a percentage of a base acreage ... determined as

ss Ibid., $\$ 4$ (d).

${ }^{5}$ Kerr Act, $\$_{3}$ (a). The Secretary has designated the minimum rate of 25 per cent.

"Ibid., $\$ 6$ (a).

${ }^{6}$ Maryland, Virginia sun-cured, and cigar leaf tobacco are not subject to the tax. Ibid., $\$_{3}$ (b). These tobacco types are defined by reference to official Department of Agriculture classifications. Ibid., \$I (i) (j) (k). In the House debate, production of the first two types of tobacco was said to be below demand. 78 Cong. Rec. 10998 (1934).

${ }^{67}$ Kerr Act, $\$_{3}(\mathrm{~b})$. The tax is not to apply to any tobacco harvested after April 30, 1936 (the end of the $\times 935-36$ crop year). Id. Section 2 of the Act provides: "It is hereby declared to be the policy of Congress to promote the orderly marketing of tobacco in interstate and foreign commerce, to enable producers of tobacco to stabilize their markets against undue and excessive fluctuations, to prevent unfair competition and practices in putting tobacco into the channels of interstate and foreign commerce, and to more effectively balance production and consumption of tobacco, and to relieve the present emergency with respect to tobacco."

serr Act, $\$ 4$ (b).

${ }^{20}$ See Knapp and Paramore, op. cit. supra note $\mathrm{r}$, supra at p. 341. The cigar leaf tobacco contracts were limited to acreage reduction. However, cigar leaf tobacco is excepted from the operation of the Act for the 1934-35 crop year.

${ }^{\infty}$ Kerr Act, \$5 (a). 
provided in any agreement between the Sccretary," and the producer. ${ }^{00}$ This basis will not be employed this year.

A significant difference between the Kerr and the Bankhead Acts lies in the function which their respective taxes are intended to fulfill. The latter tax of $5^{\circ}$ per cent is expected to compel that reduction in cotton production which the voluntary acreage reduction program alone seemed incapable of achieving. The former tax which has been fixed by the Secretary at the statutory minimum of 25 per cent was designed primarily to equalize the position of non-coöperating with that of coöperating producers. ${ }^{61}$ By taxing away the gains to be derived from non-coöperation, the Kerr Act furnishes an inducement to the coöperators to abide by the voluntary program which, if supported by an adequate number of growers, will of itself reduce tobacco production. The 25 per cent tax will not, it seems, force the non-coopperating producer into the ranks of the coöperators; it will deter those who are already there from deserting. Actually, no doubt a number of producers who, prior to the passage of the Kerr Act, had refused to join in the production adjustment program will now regard it to their best interests to do so, ${ }^{62}$ and an opportunity has been afforded them to sign agreements for the I934-35 crop..$^{62^{\wedge}}$

As in the case of the Bankbead Act, the question of the small producer and the problem of protecting those for whom production allotments could not equitably be made was encountered in framing the Kerr Bill. The solution finally effected was to authorize the Secretary to issue tax-payment warrants for this purpose in any county in an amount not in excess of 6 per cent of the amount of tobacco covered by warrants issued to all contracting producers in that county. ${ }^{63}$ At least two-thirds of

${ }^{\infty 2}$ Id. Resort to this basis would be necessary if the Act were applied to tobacco types for which no production allotments have been made. See note 59, supra.

a1 This view was expressed in a letter by Secretary Wallace quoted in the House debate as follows: "My opinion of the proposed legislation is that it does not seek to compel involuntary compliance, but does permit non-coöperatives to grow tobacco, and taxes them in an amount which would result in bringing their net income to an amount which they probably would have received in the absence of any adjustment program. If this can be accomplished in a practical manner, I can see no objection to some such emergency measure." 78 CONG. REC. ro982 (1934). Representative Marshall of Ohio insisted, however, that, "The purpose of the bill, and the only purpose of the bill, is to compel those people who have not joined in the voluntary coöperative plan to join. In other words, it lays a prohibitive tax of 25 per cent upon them if they do not join, and I say to you that it will work as a compulsory measure." Id.

5 The operation of the tax may be indicated by the following hypothetical case.. Suppose a grower of flue-cured tobacco normally planted ro acres, yielding 700 pounds to the acre. He rents 3 acres to the government, receiving rental of $\$ 52.50$. On the remaining 7 acres, he raises 4900 pounds of tobacco, sells it at 20 cents per pound, and receives $\$ 980$. In addition he obtains $12 \frac{1 / 2}{2}$ per cent of the market price, or $\$ 122.50$, as an adjustment payment. His total returns from all three sources amount to \$1 155 .

A non-coöperator having a farm of the same size and yield produces 7,000 pounds. If marketed at the same price, free from tax, this would have brought him \$1400. A 25 per cent tax, however, reduces this return by $\$ 350$, leaving him \$ro50 against the contract signer's \$1 55 . In addition, moreover, the former will have had to spend at least $\$ 45$ for additional fertilizer. He may not have had to pay for his extra wood or labor. The 25 per cent tax, therefore, does more than equalize the position of the coöperator. It is doubtful, however, whether it may justly be termed prohibitive. The non-signer gambles on the chance of an unusually high yield; 9000 pounds of equal quality would bring his return above that received by the coopperator.

'The Act provides a month's grace for this purpose. Kerr Act, \$14.

Kerr Act, $\$ 5$ (b). 
the warrants thus issued are required to be issued to growers whose allotments are I,500 pounds or less. ${ }^{84}$ Another provision authorized the Secretary to make regulations protecting the interests of share-tenants and croppers in the issuance of warrants. ${ }^{65}$ Under the tobacco contracts, landlords have generally been appointed trustees to receive adjustment payments for their tenants. ${ }^{86}$ Quite possibly, tax-payment warrants will be issued to them on the same basis.

Unlike the cotton tax-exemption certificates, the tax warrants are not transferable (except by the personal representative of a deceased producer). ${ }^{67}$ Although the tax is assessed against the first sale of any given lot of tobacco, it seems difficult to suppose that any restrictions can be effectively enforced against sales by producers who have grown more than their allotment to others who have grown less. Most tobacco is marketed by growers at auction sales conducted in warehouses throughout most of the tobacco districts, and it is probable that the tax will be levied chiefly upon such transactions. However, regulations are authorized requiring returns as to the production, sale, and delivery of tobacco to be made by producers as well as by warehousemen and processors.

The perishable character of tobacco rendered it unnecessary to parallel the provisions of the Bankhead Act regarding stored lint cotton. Tobacco must be marketed -within a limited period of time after it is cured. The only alternative is to re-dry it, and few farmers have facilities for this process. Moreover, the re-dried tobacco could be identified were it to come on the market the year following. Consequently, it seems likely that virtually all the taxable tobacco will be subjected to the tax during the year in which it is harvested.

The administration of the Act is, as in the case of the Bankhead Act, vested in the Department of Agriculture, which is employing the same machinery as was used in the voluntary tobacco programs. In general, procedural and fiscal provisions follow those of the earlier measure. The Kerr Act contains an interesting addendum in the form of provisions authorizing the Secretary to fix import quotas on cigar leaf tobacco, ${ }^{68}$ to be allocated by him among importers in a "fair and equitable" manner. Importations in excess of quotas are to be taxed, the amount of the tax to be fixed at the average sales price of domestic leaf for the preceding year times the percentage rate of the domestic tax..$^{69}$

cold.

${ }^{65}$ Ibid., 55 (f).

of Knapp and Paramore, op. cit. supra note I, supra at p. 342.

${ }^{\top}$ Kerr Act, $\$ 9$ (a). Transfer is made a criminal offense. Id. Non-transferability affords a protection to the ignorant against fraud, but whether this consideration or administrative convenience dictated this deviation from the Bankhead Act is not evident.

${ }^{\infty}$ Ibid., 515. Quotas are to be based on average imports of such tobaccos for 1932-33 and 1933-34, except that the base period for Cuban imports is I928-33. In the fixing of quotas, due regard is to be had to "the welfare of domestic producers" and "the protection of domestic consumers."

"Ibid., $\$ 16$. 